\title{
Determination Metacognitive Awareness of Physical Education Teachers
}

\author{
Işıl Aktağ ${ }^{1}$, Önder Şemşek ${ }^{2}$, Soner Tuzcuoğlu ${ }^{3}$ \\ ${ }^{1}$ Physical Education Teaching Department, Abant İzzet Baysal University, Turkey \\ ${ }^{2}$ Training Education Department, Abant İzzet Baysal University, Turkey \\ ${ }^{3}$ Physical Education Teacher, Ministry of Education, Turkey \\ Correspondence: Işıl Aktağ, Physical Education Teaching Department, Abant İzzet Baysal University, Turkey.
}

Received: June 25, 2017

Accepted: July 30, 2017 Online Published: August 4, 2017

doi:10.11114/jets.v5i9.2511

URL: https://doi.org/10.11114/jets.v5i9.2511

\begin{abstract}
In this study metacognitive awareness of physical education teachers were investigated. A total of 537 physical education teachers were participated. Data were collected by a survey which was developed by Schraw and Dennison (1994) translated to Turkish by Akın, Abacı and Çetin (2007). The mean of the metacognitive awareness level of physical education teachers is found to be 205.44. A significant difference of metacognitive awareness level in between female and male teachers was recognized. The study showed that the metacognitive awareness level of teachers did not change according to teaching experience except in planning sub-dimension.
\end{abstract}

Keywords: metacognitive awareness, physical education teachers, gender, teaching experience

\section{Introduction}

Besides to prepare individuals for career and for life, the aim of contemporary education is to educate youngsters creative, able to think critically, be aware of their own learning and productive individuals. In an effective teaching process, teachers are responsible to help students to acquire how to learn, remember and control their learning and be aware of what they learned. The success of students depends on to be aware of how they learned.

The term metacognition refers to awareness and monitoring of one's thoughts and task performance or thinking about your thinking (Flavell, 1979, as cited in Coutinho, 2007). It indicates high cognitive processes such as making plans for learning, using proper skills and strategies to resolve a problem, making approximation of performance and adjust the extent of learning (Dunlosky and Thiede, 1998, as cited in Coutinho, 2007).

Metacognition consists of two major components: metacognitive knowledge and metacognitive regulation. Metacognitive knowledge refers to knowledge of cognition such as knowledge of skills and strategies that work best for the learner and how and when to use such skills and strategies (Schraw and Dennison, 1994). Metacognitive knowledge involves declarative knowledge, procedural knowledge and conditional knowledge. Declarative knowledge is recognition of self-skills, intellectual capacity and abilities. Students can gain this knowledge through presentations, demonstrations and discussions. Procedural knowledge is the knowledge of how to perform a specific task. Students can get this knowledge through discovery, cooperative learning and problem solving. Conditional knowledge is knowledge about when and why to use skills. Students can acquire this knowledge through simulations.

Metacognitive regulation refers to activities that control one's thinking and learning such as planning, monitoring comprehension and evaluation. Planning includes separating or assignation of resources and selection of appropriate strategies. Monitoring is assessment of one's learning or strategy use. Evaluation includes an individuals' evaluation of learning process (Brown, 1987 as cited in Akın, Abacı and Çetin, 2007).

Metacognition is vital to successful learning because it lets individuals to better regulate their cognitive skills and to determine weaknesses that can be corrected by constructing new cognitive skills. According to Chatzipanteli (2013), metacognition is a teachable skill. Individuals, who are aware of their metacognitive skills, behave more strategically and productively, make plans, organize and monitor their learning better than individuals who are unaware about their metacognitive skills.

Metacognition is considered as one of the key concepts in learning and is found to be a strong anticipator of academic success (Dunning, Johnson, Ehrlinger and Kruger, 2003). Students with strong metacognition demonstrate good 
academic performance compared to their peers with weak metacognition (Coutinho, 2007). In order to present students to develop metacognitive skills teachers should have the decent level of metacognitive capability at first that is why they should develop metacognitive skills during their undergraduate education and should have the necessary competence for teaching metacognitive skills. If teachers know their own metacognitive skills, they can choose and offer students what kind of strategy they can choose when learning something. Also teachers with high metacognitive skills use different strategies, methods and techniques for fostering learning. Physical education teachers teach course theoretically as well as practical. Students have the opportunity to practice knowledge that they learned theoretically. Lessons are thought in a variety of settings such as classroom, school garden, or gym. Therefore physical education course is in a different position from the other courses.

So far previous studies are focused on metacognitive awareness only on teacher candidates and investigation of metacognition in physical education is very limited that is why this study will make contribution to the literature by providing more information about metacognition awareness in physical education teachers. Teachers need to get education to develop metacognitive skills during their undergraduate education; if they did not, in-service trainings should be provided to teachers in order to reduce their knowledge about metacognition. In order to offer students to develop metacognitive skills and strategies, teachers should have the desired level of metacognitive proficiency.

The purpose of this study was to determine the metacognition awareness level of physical education teachers according to their gender, teaching experience and school type they are working in.

\section{Material and Method}

\subsection{Data Collection Instrument}

Metacognitive Awareness Inventory (MAI) was used in this study. It is developed by Schraw and Dennison (1994) and translated into Turkish by Akın, Abacı and Çetin (2007). MAI is self-report inventory and has two subscales, which are awareness of cognitive characteristics (17 questions) and regulation of cognitive skills (35 questions). Dimensions of awareness of cognitive characteristics are declarative knowledge, procedural knowledge and conditional knowledge while dimensions for regulation of cognitive skills are planning, monitoring, evaluation, debugging strategies and information management. There are total 52 questions. Highest score is 260 and lowest score is 52 from this inventory. The inventory has 5 point Likert type scale, ranges from 1 which is always false to 5 is always true. High scores indicate strong metacognitive awareness, while low scores indicate weak metacognitive awareness. There is no reverse coding. In the reliability study of the inventory, the Cronbach alpha coefficient was found as 0.95 , test retest reliability results was found as 0.95, too (Akın, Abacı and Çetin 2007).

\subsection{Participants}

The participants of the study consist of 537 physical education teachers. 184 of them were female and 353 of them male teachers. MAI was distributed to physical education teachers' in-service teacher seminars in Ankara in 2016. Participation of the study was voluntary.

\subsection{Data Analysis}

In order to determine levels of metacognitive awareness of physical education teachers, first step was to examine whether teachers' scores from the scale were normally distributed. For this purpose, the Kolmogorov-Smirnov values of the scores were looked at. Physical education teachers' metacognitive awareness levels are normally distributed according to total score of the inventory while sub-dimensions of the inventory did not show normal distribution.

For this reason, the level of metacognitive awareness of the teachers according to gender for total score was analyzed by using Independent Samples T Test and in order to analyze of sub-dimensions Mann Whitney U test was used.

Again while the metacognitive awareness of teachers were analyzed according to the school type teachers work, the total scores of metacognitive awareness levels were analyzed by using Independent Samples $\mathrm{T}$ test and sub-dimensions were analyzed by using Mann Whitney U test.

When the metacognitive awareness of teachers were analyzed according to their teaching experience, total metacognitive scores were analyzed by using One Way ANOVA and Kruskal Wallis test was used to analyze sub-dimensions of scale.

\section{Results}

Here, findings regarding to the physical education teachers' metacognitive awareness level according to gender, school type that they are working in and teaching experience are presented and the metacognitive awareness mean of the physical education teachers was found to be $\bar{X}=205.44$. 
Table 1. T test results of physical education teachers' total metacognitive awareness scores according to gender

$p<0.05$

\begin{tabular}{llllll}
\hline & Gender & $\mathrm{N}$ & $\mathrm{X} \pm \mathrm{SD}$ & $\mathrm{t}$ & $\mathrm{p}$ \\
\hline Total metacognitive awareness & Female & 184 & $209.41 \pm 22.83$ & \multirow{2}{*}{-2.743} & \multirow{2}{*}{$0.006^{*}$} \\
& Male & 353 & $203.38 \pm 24.86$ & & \\
\hline
\end{tabular}

Table 1 presents a significant difference between female and male physical education teachers according to total metacognitive awareness $\left(\mathrm{t}_{(535)}=-2.74, \underline{\mathrm{p}}<0.05\right)$. Metacognitive awareness' mean of female physical education teachers was found as $\bar{X}=209.41$ while it was $\bar{X}=203.38$ for male physical education teachers.

Table 2. Mann Whitney U test results of physical education teachers metacognitive sub-dimension scores according to gender

\begin{tabular}{|c|c|c|c|c|c|c|c|c|c|}
\hline & Gender & Sample & $\bar{X}$ & SD & Median & $\begin{array}{l}\text { Mean } \\
\text { Rank }\end{array}$ & $\begin{array}{l}\text { Sum of } \\
\text { Ranks }\end{array}$ & $\begin{array}{c}\mathrm{Z} \\
\text { score }\end{array}$ & $\begin{array}{c}\mathrm{p} \\
\text { value }\end{array}$ \\
\hline Declerative & Female & 184 & 32.92 & 3.97 & 33.00 & 291.79 & 53689.50 & \multirow{2}{*}{-2.465} & \multirow{2}{*}{$0.014 *$} \\
\hline knowledge & Male & 353 & 32.01 & 4.08 & 32.00 & 257.12 & 90763.50 & & \\
\hline Procedural & Female & 184 & 15.54 & 2.25 & 16.00 & 276.53 & 50881.00 & \multirow{2}{*}{-0.816} & \multirow{2}{*}{0.413} \\
\hline knowledge & Male & 353 & 15.50 & 3.72 & 15.00 & 265.08 & 93572.00 & & \\
\hline Conditional & Female & 184 & 21.13 & 4.71 & 21.00 & 290.94 & 53533.00 & \multirow{2}{*}{-2.382} & \multirow{2}{*}{$0.017 *$} \\
\hline knowledge & Male & 353 & 20.27 & 2.67 & 20.00 & 257.56 & 90920.00 & & \\
\hline \multirow{2}{*}{ Planning } & Female & 184 & 28.40 & 3.68 & 29.00 & 284.87 & 52416.50 & \multirow{2}{*}{-1.717} & \multirow{2}{*}{0.086} \\
\hline & Male & 353 & 27.90 & 4.81 & 28.00 & 260.73 & 92036.50 & & \\
\hline \multirow{2}{*}{ Monitoring } & Female & 184 & 31.73 & 3.96 & 32.00 & 293.21 & 53951.50 & \multirow{2}{*}{-2.617} & \multirow{2}{*}{$0.009 *$} \\
\hline & Male & 353 & 30.69 & 4.55 & 31.00 & 256.38 & 90501.50 & & \\
\hline \multirow{2}{*}{ Evaluation } & Female & 184 & 23.72 & 3.53 & 24.00 & 297.16 & 54678.00 & \multirow{2}{*}{-3.047} & \multirow{2}{*}{$0.002 *$} \\
\hline & Male & 353 & 22.69 & 3.69 & 23.00 & 254.32 & 89775.00 & & \\
\hline Debugging & Female & 184 & 19.73 & 2.94 & 20.00 & 287.52 & 52904.50 & \multirow{2}{*}{-2.007} & \multirow{2}{*}{$0.045^{*}$} \\
\hline Strategies & Male & 353 & 19.15 & 3.80 & 19.00 & 259.52 & 91548.50 & & \\
\hline Information & Female & 184 & 36.65 & 4.50 & 36.00 & 294.97 & 54275.00 & \multirow{2}{*}{-2.807} & \multirow{2}{*}{$0.005^{*}$} \\
\hline Management & Male & 353 & 34.52 & 5.01 & 35.00 & 255.46 & 90178.00 & & \\
\hline
\end{tabular}

$*_{p}<0.05$

The data analysis of Table 2 is showing that there is a significant difference in metacognitive awareness level of physical education teachers with the exception in procedural knowledge and planning. When we look at the mean of all sub-dimensions, the female physical education teachers indicates higher metacognitive awareness scores than the male teachers.

Table 3. T test results of physical education teachers' total metacognitive awareness score according to the school type that they are working in

\begin{tabular}{llllll}
\hline & School & $\mathrm{N}$ & $\overline{\mathrm{X}} \pm \mathrm{SD}$ & $\mathrm{t}$ & $\mathrm{p}$ \\
\hline Total metacognitive awareness & State & 439 & $205.24 \pm 24.04$ & \multirow{2}{*}{-1.127} & \multirow{2}{*}{0.670} \\
& Private & 98 & $206.40 \pm 25.70$ & & \\
\hline
\end{tabular}

${ }^{*} p<0.05$

Table 3 reveals that there is no significant difference between physical education teachers and total metacognitive awareness level due to the type of school they are working $\left(\mathrm{t}_{(535)}=-0.12, \mathrm{p}>0.05\right)$. In their total metacognitive scores, teachers who work in state schools indicate $\bar{X}=205.24$, while the private school teachers $\bar{X}=206.40$. 
Table 4. Mann Whitney U results of physical education teachers' metacognitive awareness sub-dimension scores according to school type they work in

\begin{tabular}{|c|c|c|c|c|c|c|c|c|c|}
\hline & Gender & Sample & $\overline{\mathrm{X}}$ & $\mathrm{SD}$ & Median & $\begin{array}{l}\text { Mean } \\
\text { Rank }\end{array}$ & $\begin{array}{c}\text { Sum of } \\
\text { Ranks }\end{array}$ & $\begin{array}{c}\mathrm{Z} \\
\text { score }\end{array}$ & $\begin{array}{c}\mathrm{p} \\
\text { value }\end{array}$ \\
\hline \multirow{2}{*}{$\begin{array}{l}\text { Declerative } \\
\text { knowledge }\end{array}$} & State & 439 & 32.92 & 3.99 & 33.00 & 272,27 & 119524,50 & \multirow{2}{*}{-1.035} & \multirow{2}{*}{0.301} \\
\hline & Private & 98 & 32.01 & 4.36 & 32.00 & 254,37 & 24928,50 & & \\
\hline Procedural & State & 439 & 15.54 & 3.47 & 15.00 & 265,02 & 116343,50 & \multirow{2}{*}{-1.269} & \multirow{2}{*}{0.204} \\
\hline knowledge & Private & 98 & 15.50 & 2.36 & 16.00 & 286,83 & 28109,50 & & \\
\hline Conditional & State & 439 & 21.13 & 3.70 & 21.00 & 269,16 & 118160,00 & \multirow{2}{*}{-0.050} & \multirow{2}{*}{0.960} \\
\hline knowledge & Private & 98 & 20.27 & 2.65 & 21.00 & 268,30 & 26293,00 & & \\
\hline \multirow{2}{*}{ Planning } & State & 439 & 28.40 & 3.85 & 28.00 & 269,46 & 118291,00 & \multirow{2}{*}{-0.144} & \multirow{2}{*}{0.885} \\
\hline & Private & 98 & 27.90 & 6.53 & 28.00 & 266,96 & 26162,00 & & \\
\hline \multirow{2}{*}{ Monitoring } & State & 439 & 31.73 & 4.36 & 31.00 & 263,59 & 115716,00 & \multirow{2}{*}{-1.219} & \multirow{2}{*}{0.223} \\
\hline & Private & 98 & 30.69 & 4.44 & 31.00 & 293,23 & 28737,00 & & \\
\hline \multirow{2}{*}{ Evaluation } & State & 439 & 23.72 & 3.55 & 23.00 & 297.16 & 54678.00 & \multirow{2}{*}{-1.716} & \multirow{2}{*}{0.086} \\
\hline & Private & 98 & 22.69 & 4.13 & 24.00 & 254.32 & 89775.00 & & \\
\hline Debugging & State & 439 & 19.73 & 3.58 & 19.00 & 273,66 & 120138,00 & \multirow{2}{*}{-1.481} & \multirow{2}{*}{0.139} \\
\hline Strategies & Private & 98 & 19.15 & 3.32 & 19.00 & 248,11 & 24315,00 & & \\
\hline Information & State & 439 & 36.65 & 4.50 & 35.00 & 268,51 & 117878,00 & \multirow{2}{*}{-0.154} & \multirow{2}{*}{0.878} \\
\hline Management & Private & 98 & 34.52 & 5.19 & 35.00 & 271,17 & 26575,00 & & \\
\hline
\end{tabular}

According to findings in Table 4, the metacognitive awareness level of physical education teachers who teach at the state schools did not display a significant difference when compared to the private school teachers in all sub-dimensions. Both private and state school teachers declared a similar metacognitive awareness level in all sub-dimensions.

Table 5. Descriptive statistics of total metacognitive awareness according to teaching experience

\begin{tabular}{ccccccc}
\hline & $\begin{array}{c}\text { Teaching } \\
\text { Experience (year) }\end{array}$ & $\mathrm{N}$ & $\overline{\mathrm{X}}$ & $\mathrm{SD}$ & Minimum & Maximum \\
\hline & $1-5$ & 139 & 204,84 & 24,06 & 125,00 & 296,00 \\
Total Metacognitive & $6-10$ & 126 & 202,25 & 24,62 & 146,00 & 298,00 \\
Awareness & $11-15$ & 108 & 204,28 & 27,58 & 103,00 & 250,00 \\
& $16-20$ & 93 & 208,45 & 21,70 & 144,00 & 251,00 \\
& $21+$ & 71 & 210,17 & 21,73 & 164,00 & 256,00 \\
\hline
\end{tabular}
$* p<0.05$

Table 5 shows that the highest metacognitive awareness mean is attributed to the teachers who have experience of over 21 years ( $\bar{X}=210.16$ ) while the lowest mean to the teachers who are between 6-10 years ( $\bar{X}=202.25)$.

Table 6. One way ANOVA results of physical education teachers total metacognitive awareness scores according to teaching experience

\begin{tabular}{lccccc}
\hline & $\begin{array}{c}\text { Sum of } \\
\text { squares }\end{array}$ & df & Mean square & F & p \\
\hline Between groups & 3907.104 & 4 & 976.776 & 1.658 & 0.158 \\
Within groups & 313373.738 & 532 & 589.048 & & \\
$\quad$ Total & 317280.842 & 536 & & &
\end{tabular}

One way ANOVA was conducted in order to test the differences between teaching experience and metacognitive awareness level. No significant difference in teachers' metacognitive awareness level regarding their teaching experience was found. $\left(\mathrm{F}_{(4,532)}=1,658, \mathrm{p}=0,158\right)$. The highest metacognitive awareness mean is attributed to the teachers who have experience of over 21 years $(\overline{\mathrm{X}}=210.16)$ while the lowest mean to the teachers who are between $6-10$ years $(\bar{X}=202.25)$. 
Table 7. Kruskal Wallis test results of physical education teachers' metacognitive awareness sub-dimension scores according to teaching experience

\begin{tabular}{|c|c|c|c|c|c|}
\hline & Teaching Experience (years) & $\mathrm{N}$ & $\mathrm{X} \pm \mathrm{SD}$ & $\chi^{2}$ & $\mathrm{p}$ \\
\hline \multirow{5}{*}{ Declerative knowledge } & $1-5$ & 139 & $32.12 \pm 3.96$ & \multirow{5}{*}{4.460} & \multirow{5}{*}{0.347} \\
\hline & $6-10$ & 126 & $32.17 \pm 4.24$ & & \\
\hline & $11-15$ & 108 & $31.86 \pm 4.63$ & & \\
\hline & $16-20$ & 93 & $33.00 \pm 3.74$ & & \\
\hline & 21 and over & 71 & $32.82 \pm 3.28$ & & \\
\hline \multirow{5}{*}{ Procedural knowledge } & $1-5$ & 139 & $15.44 \pm 2.39$ & \multirow{5}{*}{6.452} & \multirow{5}{*}{0.168} \\
\hline & $6-10$ & 126 & $15.40 \pm 5.36$ & & \\
\hline & $11-15$ & 108 & $15.47 \pm 2.58$ & & \\
\hline & $16-20$ & 93 & $15.58 \pm 2.13$ & & \\
\hline & 21 and over & 71 & $18.82 \pm 2.09$ & & \\
\hline \multirow{5}{*}{ Conditional knowledge } & $1-5$ & 139 & $20.96 \pm 5.28$ & \multirow{5}{*}{2.484} & \multirow{5}{*}{0.647} \\
\hline & $6-10$ & 126 & $20.18 \pm 2.79$ & & \\
\hline & $11-15$ & 108 & $20.24 \pm 2.93$ & & \\
\hline & $16-20$ & 93 & $20.71 \pm 2.22$ & & \\
\hline & 21 and over & 71 & $20.78 \pm 2.46$ & & \\
\hline \multirow{5}{*}{ Planning } & $1-5$ & 139 & $27.50 \pm 3.91$ & \multirow{5}{*}{15.732} & \multirow{5}{*}{$0.003 *$} \\
\hline & $6-10$ & 126 & $27.45 \pm 3.86$ & & \\
\hline & $11-15$ & 108 & $28.20 \pm 6.34$ & & \\
\hline & $16-20$ & 93 & $28.94 \pm 3.68$ & & \\
\hline & 21 and over & 71 & $28.96 \pm 3.57$ & & \\
\hline \multirow{5}{*}{ Monitoring } & $1-5$ & 139 & $30.99 \pm 4.36$ & \multirow{5}{*}{6.292} & \multirow{5}{*}{0.178} \\
\hline & $6-10$ & 126 & $30.51 \pm 4.13$ & & \\
\hline & $11-15$ & 108 & $30.94 \pm 4.72$ & & \\
\hline & $16-20$ & 93 & $31.51 \pm 4.57$ & & \\
\hline & 21 and over & 71 & $31.66 \pm 4.06$ & & \\
\hline \multirow{5}{*}{ Evaluation } & $1-5$ & 139 & $23.11 \pm 3.68$ & \multirow{5}{*}{2.423} & \multirow{5}{*}{0.659} \\
\hline & $6-10$ & 126 & $22.81 \pm 3.66$ & & \\
\hline & $11-15$ & 108 & $22.66 \pm 4.19$ & & \\
\hline & $16-20$ & 93 & $23.29 \pm 3.36$ & & \\
\hline & 21 and over & 71 & $23.59 \pm 3.15$ & & \\
\hline \multirow{5}{*}{ Debugging Strategies } & $1-5$ & 139 & $19.32 \pm 4.55$ & \multirow{5}{*}{6.485} & \multirow{5}{*}{0.166} \\
\hline & $6-10$ & 126 & $18.99 \pm 2.96$ & & \\
\hline & $11-15$ & 108 & $19.46 \pm 3.23$ & & \\
\hline & $16-20$ & 93 & $19.85 \pm 2.97$ & & \\
\hline & 21 and over & 71 & $19.20 \pm 3.32$ & & \\
\hline \multirow{5}{*}{ Information Management } & $1-5$ & 139 & $34.81 \pm 4.46$ & \multirow{5}{*}{6.573} & \multirow{5}{*}{0.160} \\
\hline & $6-10$ & 126 & $34.28 \pm 4.82$ & & \\
\hline & $11-15$ & 108 & $34.71 \pm 5.29$ & & \\
\hline & $16-20$ & 93 & $34.89 \pm 4.25$ & & \\
\hline & 21 and over & 71 & $36.54 \pm 5.54$ & & \\
\hline
\end{tabular}

${ }^{*} p<0.05$

When Table 7 is explored metacognitive awareness level of teachers were analyzed according to experience using sub-dimensions. A significant difference was found only in planning sub-dimension $\left(\chi_{(2,537)}^{2}=15.73, p<0.05\right)$. Mann Whitney $\mathrm{U}$ test was conducted to find out where the difference comes from. As a result, it was found that teachers who have 1-5 years of experience showed a significant difference when compared to the teachers who have 16-20 ( $\mathrm{z}=-2.95$, $\mathrm{p}=0.003)$ and 21 and over $(\mathrm{z}=2.63, \mathrm{p}=0.008)$ years of experience in their metacognitive awareness. Similarly, teachers who have 6-10 years of experience showed a significant difference when compared to the teachers who have 16-20 $(\mathrm{z}=-2.89, \mathrm{p}=0.004)$ and 21 and over $(\mathrm{z}=-2.59, \mathrm{p}=0.009)$ years of experience in their metacognitive awareness.

\section{Discussion}

The purpose of this study was to determine metacognitive awareness level of physical education teachers according to their gender, school type they work and teaching experience. When we look at the teachers' metacognitive awareness using total scores whether it changes according to gender, gender emerged as a determinant factor.

However, when analysis is made according to the sub-dimensions of the scale, there is no significant gender difference in planning and procedural knowledge but gender was found to have made a significant difference in declarative, 
conditional, monitoring, evaluation, debugging strategies and information management sub-dimensions. Those findings are consistent with the findings of Dilci and Kaya (2012), Gül, Köse and Yılmaz (2015), Küçük Kılıç, Cihan and Öncü (2015), Tunca and Şahin (2014) and Sırmacı and Taş (2016), that female teachers or teacher candidates scored higher metacognitive awareness than males. Unlike the results obtained in this study, Baykara (2011), Yokuş and Yürüdür (2015), Solmaz Yalız (2014), Theodosiu, Mantis and Papoioannou (2008), and Ghonsooly, Khojouy and Mohjoobi (2014),Tüysüz, Karakuyu, Bilgin (2008), Okçu and Kahyaoğlu (2007) stated gender did not emerged as a determinant factor of metacognition.

This study shows some differences when compared to the other similar studies. While they study the prospective teachers, we investigated physical education teachers' metacognitive levels. Looking at the studies on metacognition in general, a few studies are initiated in physical education. Most of the studies are conducted in primary school teaching and science teaching areas. This is why the metacognitive awareness shows a difference in gender while it makes no difference in other studies.

According to our findings, no significant difference is found in physical education teachers' both total and sub-dimensions of metacognitive awareness whatever the type of school they are working in. In literature, no study was found related to this subject. Results are reasonable since teachers come from similar undergraduate education programs. So, we can conclude that the school type is not a factor in the influence of metacognitive awareness of teachers.

Moreover, the results from metacognitive awareness regarding teaching experience revealed that only significant difference was found in planning sub-dimension. Specifically, more experienced teachers have stronger metacognitive awareness level than less experienced ones.

Dilci and Kaya (2012) and Okçu and Kahyaoğlu (2007) got similar results as ours. They stated teachers metacognitive awareness did not change according to teaching experience. Physical education is a course of practice so teachers need to be careful about the planning of the courses organization. Materials to be used, field, teaching methods should be planned and prepared due to the number of students and the purpose of the course. So, years of experience in planning course, have had a positive influence on teachers' metacognitive awareness.

Teachers with strong metacognitive awareness are the ones who make a difference in education. Therefore, it is necessary for teachers to prepare surroundings to improve metacognitive skills during their undergraduate education as well as with the support of in-service trainings.

Limitation of the study, this study was carried out with restricted number of physical education teachers therefore future studies should be conducted with more teachers.

\section{Conclusion}

In conclusion, based on the information obtained in this study, physical education teachers' metacognitive awareness level was varied according to gender. Working in state or private schools did not influence teachers' metacognitive awareness. Furthermore, when the influence of teaching experience on metacognitive awareness was explored experience in total score was not emerged as a determinant factor. However, when it was looked for sub-dimensions such as planning, more experienced teachers have had stronger metacognitive awareness than less experienced teachers.

\section{References}

Akın, A., Abacı, R., \& Çetin, B. (2007). The validity and reliability of the Turkish version of the metacognitive awareness inventory. Educational Sciences: Theory and Practice, 7(2), 655-680.

Baykara, K. (2011). A study on teacher efficacy perceptions and metacognitive learning strategies of prospective teachers. Hacettepe University Journal of Education, 40, 80-92.

Çetin, B. (2015). An investigation of teacher candidates' metacognitive skills according to their year of study at Çanakkale. Educational Research and Review, 10(1), 10-16. Doi:10.5897/ERR2014.14.1903

Chatzipanteli, A., Grammatikopoulus, V., \& Gregoriadis, A. (2013). Development and evaluation of metacognition in early childhood education. Early Chailhood Development and Care. http://dx.doi.org.10.1080/03004430.2013.861456

Coutinho, S. A. (2007).The relationship between goals, metacognition, and academic success. Educate, 7(1), 39-47.

Dilci, T., \& Kaya, S. (2012). Examination of metacognitive awareness levels of class teachers teaching 4th and 5th grades in terms of various variables. SDU Faculty of Arts and Sciences Journal of Social Sciences, 27, 247-267.

Dunning, D., Johnson, K., Ehrlinger, J., \& Kruger, J. (2003). Why people fail to recognize their incompetence. Current Directions in Psychological Science, 12(3), 83-87. https://doi.org/10.1111/1467-8721.01235

Ghosooly, B., Khajavy, G. H., \& Mahjoobi, F. M. (2014). Self-efficacy and metacognition as predictors of Iranian 
teacher trainees' academic performance: A path analysis approach. Social and Behavioral Sciences, 98, 590-598.

Gül, Ş., Köse, E., \& Yılmaz, S. (2015). Compared to different variable of prospective biology teachers' metacognitive awareness. Hasan Ali Yücel Journal of Education Faculty, 12(23), 83-91.

Küçük, K. S., Cihan, H., \& Öncü, E. (2015). Metacognitive learning strategies and academic self-efficacy of pre-service physical education teachers and their attitudes towards the profession of teaching. Hacettepe Journal of Sport Sciences, 26(3), 77-89.

Okcu, V., \& Kahyaoğlu, M. (2007). Primary School Teachers’ Metacognitive Learning Strategies. Journal of Suleyman Demirel Institute of Social Sciences, 2(6), 129-144.

Schraw, G., \& Dennison, R. S. (1994). Assessing metacognitive awareness. Contemporary Educational Psychology, 19, 460-475. https://doi.org/10.1006/ceps.1994.1033

Sırmacı, N., \& Taş, F. ( 2016). Teacher self-efficacy and metacognitie learning strategies of pre-service mathematics teachers. Hacettepe University Journal of Education, 31(3), 551-563. https://doi.org/10.16986/HUJE.2016015698

Theodosiou, A., Mantis, K., \& Papaioannou. (2008). Student self-reports of metacognitive activity in physical education classes. Age group differences and the effect of goal orientations and perceived motivational climate. Educational Research and Review, 3(12), 353-364.

Tunca, N., \& Alkın-Şahin, S. (2014). The relationship between pre-service teachers' metacognitive learning strategies and academic self-efficacy. Anadolu Journal of Educational Sciences International, 4(1), 47-56.

Tüysüz, C., Karakuş, Y., \& Bilgin, İ. (2008). Öğretmen adaylarının üst biliş düzeylerinin belirlenmesi. AİBய̈ Journal of Social Sciences, 2(17), 147-158. https://doi.org/10.11616/AbantSbe.225

Yalız, D. S. (2014). The metacognition levels of students: A research school of physical education and sports at Anadolu University. Journal of Human Sport and Exercise, 9(1), 398-408. https://doi.org/10.14198/jhse.2014.9.Proc1.25

Yokuş, T., \& Yürüdür, F. E. (2015). The correlation between metacognitive awareness and self-efficacy levels in pre-service music teachers. Turkish Journal of Arts and Social Sciences, 1(1), 22-34.

\section{Copyrights}

Copyright for this article is retained by the author(s), with first publication rights granted to the journal.

This is an open-access article distributed under the terms and conditions of the Creative Commons Attribution license which permits unrestricted use, distribution, and reproduction in any medium, provided the original work is properly cited. 